The $5^{\text {th }}$ International Conference on Family Business and Entrepreneurship

\title{
TEACHING READINESS AND CAPABILITY OF ISLAND SCHOOL TEACHERS IN THE DISTRICT OF CONCEPCION ILOILO
}

\author{
Lorelie Sylvie F. Sente ${ }^{1}$, Ivy G. Gorriceta ${ }^{2}$ \\ ${ }^{1,2}$ Faculty of Business, Colegio de la Purisima Concepcion,Corresponding author: sgs@purisima.edu.ph
}

\begin{abstract}
Teaching readiness and capability of teachers' mirror the quality of students' achievements. The determination of readiness and capability of teachers particularly in island schools identified the extent of teachers' competence despite online skill inadequacies amidst the pandemic. The study included a relationship of personal factors that have bearing on teachers' readiness and capability. Descriptive-correlational research design was used with simple random sampling. One hundred seventy-two (172) teachers provided the needed data. Data were gathered through a researcher-made questionnaire. The statistical tools used were descriptive statistics, $t$-test and One-Way ANOVA for significant difference and Pearson $r$ for relationship of teaching readiness and level of teachers' capability. The findings highlighted teachers' teaching readiness as high particularly in the preparation of instructional materials and average as to technological requirements such as in place internet access, with computers, laptops, other digital gadgets and delivery of students' academic needs using technology. While the teachers were highly capable in online skills like creating models, guides, online assessment materials and use of articles, videos and infographics. In the new normal class management, teachers demonstrated very high capability in stimulating student's curiosity in learning by integrating real life situations, detailed modules and providing an engaging environment through oral communication. No significant differences were found on the degree of teaching readiness and level of teachers' capability when respondents were grouped according to their selected profile. However, teaching readiness has significant bearing on teachers' online capability.
\end{abstract}

Keywords: Teaching, Readiness, Capability, Island schools

\section{Introduction}

Recently decision makers in the field of education in different countries, including the State of Kuwait, prioritized integration of ICT in the curriculum and all other elements relevant to the whole process of teaching and learning. They deliberated on the issue of developing teachers' competencies to integrate technology into the curriculum and to enhance their abilities to create technology-based teaching and learning environments (Lim et al., 2011; Kintu, Zhu \& Kagambe, 2017). The shift was from the traditional instructional materials to digital and innovative resources where teachers need to be prepared for the transformational curriculum. These competencies include skills and knowledge in the use of digital tools in all curriculum domains and making students' learning extend beyond the classroom (Bonanno, 2011; Kalisch et al., 2017) and may become resilient or have the ability of bouncing back despite adversity. The successful implementation of digital technology relies heavily on teachers' readiness and willingness to adopt technology. Teachers can integrate digital technology to supplement and support the curriculum, facilitate teachers' work, and encourage student centered learning (Ertmer et al., 2012). Several models exist to blend learning, with some emphasizing more face-to-face (F2F) delivery and others more online 
delivery (Fleck, 2012). Setting is another decision factor to consider, since a lack of student computer technology or Internet access in home can detract the effectiveness of blended learning (Yapici \& Akbayin, 2012; Marzano \& Melluzzo 2017), and may necessitate the choice of school-based blended models as positive effects of four blended learning programs: Cognitive Tutor, LeapTrack, READ 180, and Time To Know were recognized. In the Philippines, DepEd adopted Distance Learning Delivery modalities due to COVID-19 pandemic and may be implemented through any of the following: Modular Distance Learning (MDL), Online, Distance Learning (ODL), TV-Video/RBI, or Blended Distance Learning. A learner may adopt either Digital Modular Distance Learning (DMDL) or Printed Modular Distance Learning (PMDL). Learners with devices at home like laptop, desktop, or tablet, may adopt DMDL. The SLMs in different digital formats such as flat PDF, educational videos, audio lessons, e-SLMs and others may be stored in a $\mathrm{CD} / \mathrm{DVD} / \mathrm{USB}$ flash drive/pen drive while the printed SLM shall be used by learners adopting PMDL. A class adopting Online Distance Learning shall follow the regular planning standards in the organization of classes set by the DepEd. It shall be applicable in schools where both the teachers and learners have access to digital devices, such as laptops, tablets, smartphones, and desktop computers, with available online resources and internet connectivity (DepED Memorandum DM-CI-202000162). Consequently, public school teachers assigned in an island school in the District of Concepcion experienced difficulty due to limited digital skills and lack the competencies to handle blended learning more particularly in online teaching. In order to address the demands of the 'new normal' trend in education, the teachers need intensive training for the development of digital technology competencies and access to online resources. Likewise, teachers posited the lack of necessary competence to adopt online distance learning as evidenced by their lack of training on ICT integration and application in instruction.

\section{Statement of the Problem}

This study investigated the relationship between teaching readiness and capability of island school teachers in the District of Concepcion. Specifically, this study sought to answer the following problems:

1. What is the degree of teaching readiness in terms of technological requirements and instructional materials of island school teachers in the District of Concepcion?

2. What is the level of teachers' capability in terms of online skills and new normal class management of island school teachers in the District of Concepcion?

3. Is there a significant difference in the degree of teaching readiness when respondents are grouped according to age, sex, highest educational attainment, length of service, monthly income, civil status, and residence?

4. Is there a significant difference in the level of teachers' capability when respondents are grouped according to age, sex, highest educational attainment, length of service, monthly income, civil status, and residence?

5. Is there a significant relationship between the degree of teaching readiness and level of teachers' capability of island school's teachers in the District of Concepcion?

\section{Hypotheses of the Study}

Based on the problems presented, the following hypotheses were verified:

1. There is no significant difference in degree of teaching readiness when respondents are grouped according to age, sex, highest educational attainment, length of service, monthly income, civil status and residence.

2. There is no significant difference in the level of teachers' capability when respondents are grouped according to age, sex, highest educational attainment, length of service, monthly income, civil status and residence.

3. There is no significant relationship between the degree of teaching readiness and level of teachers' capability in island schools in the District of Concepcion.

\section{Theoretical framework}

The study was anchored on the ecological systems theory developed by Bronfenbrenner (1974) cited by (Rosa \& Tudge, 2013; Vélez-Agosto et al., 2017) viewed child development as a complex system of relationships affected by multiple levels of the surrounding environment, from immediate setting of family and school to broad cultural values, laws, and customs. To study about the child's development, a review on the child and her immediate environment as well as her interaction with the larger environment may be observed in a bigger picture. The microsystem is the most influential level of ecological systems theory. 
The theory was deemed appropriate for the present study since Bronfenbrenner's ecological systems theory has implications on the educational practice that has been used to link psychological and educational theory to early educational curriculums and practice. In addition, the theory emphasized that the environment has something to do with teaching and learning. Hence, it is assumed that the environment of the teachers, which is on the island, affects the delivery of teaching and learning. The developing child is the center, and all that occurs within and between the five ecological systems intended to benefit the child in the classroom. As emphasized teachers and parents should keep good communication with each other and work together to assist the child which Santana (2014) also supported. When parents and teachers have a good relationship, it would shape the child's development positively. Likewise, the child must also be active in their learning, engaged both academically and socially as Đurišić \& Bunijevac (2017) stressed.

\section{Conceptual Framework}

This study considered the socio-demographic profile of the respondents such as age, sex, and educational attainment, length of service, monthly income, civil status, and residence as independent variables. The degree of teaching readiness in terms of technological requirements and instructional materials; and level of teachers' capability considering online skills and new normal class management are the dependent variables. This study was based on the concept that the socio-demographic profile of the respondents was perceived to affect the degree of teaching readiness of teachers and level of teachers' capability. It also presents that the degree of teaching readiness is associated with the level of teachers' competence.

\section{Independent Variable}

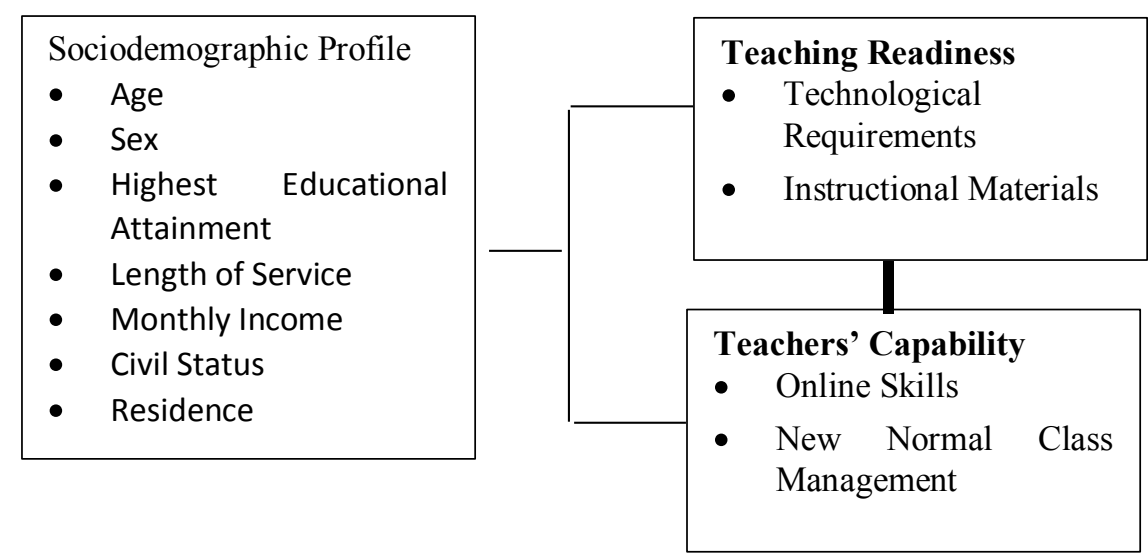

Figure 1. Schematic diagram showing the relationship of the variables.

\section{Literature Review}

In K-12 implementation, the most common definition of BL describes students as learning "at least in part through online learning, with some element of student control over time, place, path and/or pace" (Horn and Staker, 2014). As BL is used more extensively in K12 schools, more teachers must develop specialized skills for teaching in blended environments. Important insights into the growing demand for skilled blended teachers and the specific skills that are required to teach successfully in blended learning environments. Specifically, this literature review will address similarities and differences of technology integration, blended teaching, and fully-online teaching, along with teaching competencies needed in these different modalities (Pulham and Graham 2018, Pulham, Graham, and Short, 2018). The growth of K-12 blended learning raises the need for teachers who have the skills to teach effectively in blended contexts. Effective online teaching requires skills beyond those required in a traditional context. By extension, effective blended teaching requires teachers to have both online and traditional teaching skillsets, as well as the ability to seamlessly and strategically integrate the two. Factors that determine the successful use of technology in education is teaching experience, which is contrary to the current findings of the study. Findings of existing research (Ertmer et al., 2012) confirmed that there is a relationship between teachers' readiness to use technology and years of teaching experience. While some research (Singh and Chan, 2014) reported that novice teachers implement technology in their instruction more than teachers with high experience do, other research showed the opposite and declared that experienced teachers implement technology more than beginner teachers do. 
A research on teachers' professional development on online teaching by Rice and Dawley (2009) found that only $20.0-38.1 \%$ of $\mathrm{K}-12$ online teachers received professional development prior to teaching online, with $28.3-38.1 \%$ receiving their training during their first year of online teaching. Teachers need to submit themselves to trainings that will enhance their teaching capability and skills (Kennedy et. In recent years, decision makers in the field of education in different countries, including the State of Kuwait, have been paying more attention to the integration of ICT into the curriculum and all other elements relevant to the whole process of teaching and learning. They have always payed attention to the issue of developing teachers' competencies to integrate technology into the curriculum and to enhance their abilities to create technology-based teaching and learning environments (Lim, Chai, and Churchill, 2011). However, teachers may not be ready to integrate technology and may not have adequate knowledge and skills to utilize technology to support the curriculum. The National Council for Accreditation of Teacher Education (NCATE) emphasized that teachers must take advantage of technology for instruction and be prepared to use technology effectively in the classroom (Afshari, Ghavifekr, Siraj, and Jing, 2013). In order to be ready to integrate technology in the curriculum, teachers must be provided with a solid foundation of knowledge and skills in digital media and develop new understandings, new approaches, new roles, new forms of professional development, and new attitudes about technology integration (Ruggiero and Mong, 2015; Teachers need to make a paradigm shift in their conception of curriculum and move from printed traditional curriculum to digital curriculum. The successful implementation of digital technology into the curriculum relies heavily on teachers' readiness and willingness to adopt technology (Singh and Chan, 2014; Teachers can integrate digital technology to supplement and support the curriculum, facilitate teachers' work, and encourage student centered learning (Ertmer, Ottenbreit-Leftwich, Sadik, Sendurur, and Sendurur, 2012). These factors are considered crucial for the success of any technological innovation in teaching and learning ( $\mathrm{Ng}, 2015)$. A comparative study of pedagogy and ICT use in schools in 22 different countries concluded that teachers' pedagogical and technical competence in the use of technology are significant predictors for technology adoption in teaching practice (Law and Chow,2008).

Teachers' readiness to adopt technology in their teaching practices has evolved in the last few years along with different dimensions ranging from school's readiness, to the availability of resources and teacher's competence development (Bonanno, 2011). With COVID 19 pandemic, integration of ICT in instruction is inevitable, thus teachers need to equip themselves by learning technology applications to teaching. Technology readiness is another critical dimension connected with students' learning in the blended learning environment. Existing studies have been focused on students' adoption of learning technologies and the determinant factors, for instance, personal innovation, perceived usefulness, performance expectancy, effort expectancy, social influence, perceived playfulness, self-management of learning, using the Technology Acceptance Model (TAM) and Unified Theory of Acceptance and User of Technology (UTAUT) (Liu, Li, and Carlsson, 2010).

Challenges to the design of effective BL course have been classified into four types, which includes incorporating teaching flexibility, facilitating students' interaction, facilitating learning process, and fostering affective learning climate by Boelens, De Wever, and Voet in 2017. Institutional blocks including organizational readiness, adjacent technical resources, motivated faculty, professional development for teachers and students' maturity and readiness for blending learning are all concerns. The success of teaching and learning has been linked to availability of resources and that to support poorly performing schools, educational authorities must increase student levels and competencies by the use of these resources for students to be ready for National Assessments (UNESCO, 2015). Their view claimed that these resources made teaching and learning easier thus upping students' academic outcomes (Abdo and Semela (2010) in Ethiopia; Resources ranging from textbooks to library books to websites, are variety of resources to help teachers meet the needs and pique the interest of their learners. Some of the issues that might deter faculty members from teaching online include wondering if they are qualified to teach online, how to maintain their own identities and attributes as instructors, what the learners' demographic might be, how to meet discipline-related demands, what kind of training they would need, how to be successful online instructors, how to assess and evaluate learning outcomes, and how to deal with stress and feelings of frustration while making the transition to online learning environments (Alman and Tomer, 2012). The principles of feedback, andragogy, constructivism, and transformative learning seem to be more appropriate to proclaiming the learner-centered approach, which is one of the online learning foundations. Online instructors must pay attention to what they need to create, develop, manage their online courses and how to effectively communicate with the learners in the absence of physical presence and interaction.

The roles, characteristics, competencies, and skills that one requires to be a competent and successful online instructor should be identified and highlighted by educational institutions, online learning organizations 
and authorities, and online learning theorists. Online instructional staff better understand their role as online faculty if they are introduced to examples of exemplary online instructors and consider them role models. Teaching online necessitates a commitment to the principles of online learning to be able to create and maintain teaching, social, and cognitive presence. (c) teaching, learning, and developing the curriculum; Effective online instructors should understand the fundamentals of online teaching and pedagogy. These principles and strategies include: Learning theories, such as learning styles, the adult learning theory, the learner-centered approach, and collaborative learning; Online teachers must be able to do the following: expressing and mastering extensive knowledge of the content; This will establish an effective online learning structure and a more effective blended learning environment. Although online learning relies heavily on technology, there is no imperative need for online instructors to be technologically advanced: Accessing various technological resources and tools, such as email, internet browsers, LMSs, text and video chat applications, and productivity software and applications.

\section{Research Method}

The descriptive-correlation research design utilizing quantitative data was used in the study. Descriptive study involves collection of data to test the hypothesis, answer questions regarding the condition of the subject of investigation and report the real situations and conditions (Reganit, 2010). The study investigated factors, including the nature of the relationship between two or more variables and the theoretical model that might be developed and tested to explain resultant correlations. The determined the degree of teaching readiness and level of capability of public school's teachers in island schools in the District of Concepcion this school year 2020-2021. The respondents were 172 from the island school teachers in the District of Concepcion, a coastal municipality on the north-eastern part of Panay Island with 25 barangays, 14 of which are island barangays in the Province of Iloilo. The District of Concepcion has 10 primary island schools, 11 elementary island schools, and 2 secondary island schools. This study used a researcher-made questionnaire which contained scales on the degree of teacher's readiness and level of teachers' capability. The independent variables composed of age, sex, highest educational attainment, length of service, monthly income, civil status and residence. The content validity and reliability was established using Cronbach Alpha with a value of .987. Descriptive data were analyzed using frequency count and mean (4.21-5.00 Very High, 3.41-4.20- High, 2.61-3.40-Average, 1.81-2.60- Low, 1.00-1.80-Non-existent) while inferential data were processed using t-test ( sex and residence and F-test for age, Highest Educational attainment, Length of service, monthly income and Civil status) for independent samples, One-way ANOVA and Pearson r.

\section{Results and Discussion}

Degree of Teaching Readiness of Island School Teachers in the District of Concepcion

Results on the degree of teaching readiness of island school teachers considering technological requirements and instructional materials were expressed in Table 1.

Table 1. Degree of teaching readiness of island school teachers in the District of Concepcion.

\begin{tabular}{lcc}
\hline \multicolumn{1}{c}{ Degree of Teaching Readiness } & Mean & Verbal Interpretation \\
\hline Technological Requirements & 3.28 & Average \\
Instructional Materials & 3.58 & High \\
Grand Mean & 3.43 & High \\
\hline
\end{tabular}

Results revealed both components had means of 3.28 for technological requirements, 3.58 for instructional materials, and 3.43 grand mean interpreted as high. The degree of teaching readiness teachers in terms of technological requirements was average indicated by grand mean of 3.28. With increasing possibilities of choice, it is important teachers do not only teach, but also dedicate themselves to training. Along with better knowledge and experience, it shall become easier for teachers to use ICT and the use of technology would become more common and with the time ICT may slowly displace part of the classical methods of teaching. However, it is important to note that teachers must find the perfect balance between those" two worlds" and shall manage to get the most out of both. Institutional blocks including organizational readiness, adjacent technical resources, motivated faculty, professional development for teachers and students' maturity and readiness for blended learning are all major concerns. This implies that modularized delivery mode is utilized in the teaching and learning structures of island schools in the District of Concepcion. As Liu, Li, and Carlsson, (2010) technology readiness is another critical dimension connected with students' 
learning in the blended learning environment which included personal innovation, perceived usefulness, performance expectancy, effort expectancy, social influence, perceived playfulness, self-management of learning.

Table 2. Degree of teaching readiness of island school teachers in the District of Concepcion in terms of technological requirements.

\begin{tabular}{|c|c|c|}
\hline Statements & Mean & $\begin{array}{c}\text { Verbal } \\
\text { Interpretation }\end{array}$ \\
\hline 1. I have internet access in place. & 3.53 & High \\
\hline 2. I use social media to communicate with students. & 2.75 & Average \\
\hline $\begin{array}{l}\text { 3. I use physical structure of technology like computers, laptops and other } \\
\text { digital gadgets. }\end{array}$ & 4.01 & High \\
\hline $\begin{array}{l}\text { 4. I use electronic learning activities that encourage students to be critical } \\
\text { thinkers. }\end{array}$ & 2.85 & Average \\
\hline 5. I use ICTs to download files from the internet. & 3.95 & Average \\
\hline $\begin{array}{l}\text { 6. I use ICT instruction software like game applications, word processor } \\
\text { and web browsing in teaching. }\end{array}$ & 2.69 & Average \\
\hline 7. I use digital formative assessment tools for students' learning outputs. & 2.70 & Average \\
\hline $\begin{array}{l}\text { 8. I use learning management system (e.g., Microsoft } 365 \text {, web browser, } \\
\text { media player, photo editor) to supplement my teaching. }\end{array}$ & 2.86 & Average \\
\hline 9. I deliver student's academic needs using technology. & 3.53 & High \\
\hline 10. I use mobile device connected to the internet. & 3.88 & High \\
\hline Grand Mean & 3.28 & Average \\
\hline
\end{tabular}

Instructional materials. Table 3 disclosed degree of teaching readiness in terms of instructional materials with grand mean of 3.58 interpreted as high. Teaching and learning resources motivate and encourage learners to utilize more than one sense hence increasing their attention and retention capacity. In school activities and teaching utilities, teachers should make sure each module is consist of group of diversity of teaching practices enabling the student to choose from what suits him from application and referral activities to achieve the required goals with the support of the variety of the teaching utilities including audio, visual, video and touch, the teaching resources with its capabilities and the tools and equipment.

The success of teaching and learning was linked to availability of resources that support poorly performing schools, educational authorities must increase student levels and competencies by use of these resources for students to be ready for National Assessments (UNESCO, 2015). They underscored the importance of instructional resources ((Monda, 2012; Wamalwa, 2016) from textbooks, journals and websites in the effective delivery of content to students by teachers in secondary/primary schools for the purpose of bettering their academic achievement.

Table 3. Degree of teaching readiness of island school teachers in the District of Concepcion in terms of instructional materials.

\begin{tabular}{|c|c|c|c|}
\hline & Statements & Mean & Verbal Interpretation \\
\hline & I use modules in teaching. & 4.56 & Very High \\
\hline & $\begin{array}{l}\text { I use the internet to conduct researches to make learning activities } \\
\text { for my lessons. }\end{array}$ & 3.96 & High \\
\hline 3. & $\begin{array}{l}\text { I develop interactive media learning materials to better teach my } \\
\text { students. }\end{array}$ & 3.33 & Average \\
\hline & $\begin{array}{l}\text { I use formative, summative, and quizzes as assessment tools to } \\
\text { determine learning outcomes. }\end{array}$ & 4.24 & Very High \\
\hline & I use online references to support the learning activities of students. & 3.67 & High \\
\hline & I use e-books to supplement modules. & 3.23 & Average \\
\hline & $\begin{array}{l}\text { I use simulation/animation/ applications that enhance content for a } \\
\text { lesson. }\end{array}$ & 2.87 & Average \\
\hline & I teach with presentations using computers and projectors. & 2.78 & Average \\
\hline & I create multimedia presentations using ICTs. & 2.92 & Average \\
\hline & I use office applications (e.g. word processors, spreadsheets, etc.). & 4.22 & Very High \\
\hline & Grand Mean & 3.58 & High \\
\hline
\end{tabular}


Level of Teachers' Capability in Island Schools in the District of Concepcion

The level of teacher's capability of island schools' teachers considering online skills and new normal class management are expressed in Table 3. Findings showed, the level of teachers' capability was high with mean of 3.77 for online skills and 4.37 for new normal class management and grand mean of 4.07 considered high.

Table 4. Level of teachers' capability in island schools in the District of Concepcion.

\begin{tabular}{lcc}
\hline \multicolumn{1}{c}{ Level of Teacher's Capability } & Mean & Verbal Interpretation \\
\hline Online Skills & 3.77 & High \\
New Normal Class Management & 4.37 & Very High \\
Overall Mean & 4.07 & High \\
\hline
\end{tabular}

Results indicated teachers' readiness in terms of online skills and new normal class management. They have digital skills but the need for enhancement was apparent in some teachers. As Alma and Tomer (2012) stated the impact of lack of preparation is magnified in online learning environments where principles of feedback, andragogy, constructivism, and transformative learning seem to be more appropriate.

Online skills. The level teachers' capability in island schools in the District of Concepcion in terms of online skills had a grand mean of 3.77 interpreted as high. Results implied teachers acknowledge the significance of intellectual property rights and design practically applied in the teaching-learning process. They give proper honour and credit to the rightful owner and effective feedback mechanisms on students' performance. This implied teacher do not need to be experts when it comes to the use of technology, however they should at least equip themselves with the basic technological skills. While (Abdous, 2011; Munoz-Carril et al., 2013) disclosed to being aware of the technical potential of, and procedures used to create, e-content, such as e-books and instructional videos; and being alert to the latest updates and innovations of educational technology and software.

Table 5. Level of teachers' capability in island schools in the District of Concepcion terms of online skills.

\begin{tabular}{|c|c|c|}
\hline Statements & Mean & $\begin{array}{c}\text { Verbal } \\
\text { Interpretation }\end{array}$ \\
\hline $\begin{array}{l}\text { 1. I know the primary concepts and structures of effective online } \\
\text { instruction. }\end{array}$ & 3.69 & High \\
\hline 2. I create interactive learning experience to enrich student learning. & 3.63 & High \\
\hline 3. I have knowledge of the data privacy act. & 3.90 & High \\
\hline $\begin{array}{l}\text { 4. I use a range of online platforms that effectively support student } \\
\text { learning. }\end{array}$ & 3.22 & Average \\
\hline $\begin{array}{l}\text { 5. I respect intellectual property rights and acknowledge designs that I } \\
\text { use in my teaching. }\end{array}$ & 4.22 & Very High \\
\hline $\begin{array}{l}\text { 6. I model, guide, and assist students in relation to the social, legal, } \\
\text { ethical and safe behavior related to technology use. }\end{array}$ & 3.85 & High \\
\hline $\begin{array}{l}\text { 7. I promote student performance and success through clear objectives, } \\
\text { prompt response and regular feedback. }\end{array}$ & 4.22 & Very High \\
\hline $\begin{array}{l}\text { 8. I demonstrate teaching competence in creating and implementing } \\
\text { assessments in online learning environments. }\end{array}$ & 3.75 & High \\
\hline $\begin{array}{l}\text { 9. I interact in a professional, effective manner with colleagues, parents } \\
\text { and other members of the community to support student's success in } \\
\text { an online environment. }\end{array}$ & 4.01 & High \\
\hline $\begin{array}{l}\text { 10. I encourage students to read/watch selected educational social media } \\
\text { content (e.g., blogs, articles, videos, infographics) that would help } \\
\text { them learn effectively in the online environment. }\end{array}$ & 3.23 & Average \\
\hline Grand Mean & 3.77 & High \\
\hline
\end{tabular}

New normal class management. Table 6 shows the level of class management of public schools teachers in the new normal in island schools in the District of Concepcion had a grand mean of 4.37 and interpreted very high. The highest mean of 4.58 on always accommodate students' questions and address them 
immediately. The result implies that teachers established a strong communication and partnership with their students. Effective communication creates a positive class environment and achievement; sharing are important factors on learning performance. Teachers need to give students more opportunities to interact with each other. All of these can lead to a positive impact on learning performance. Results exhibited learning community can develop and increase student performances as well as their satisfaction. Teachers develop new alternative and varied approaches to monitor children's learning (from assessing to remediating learning losses) during the COVID crisis, including both formative and summative methods.

Table 6. Level of teachers' capability in island schools in the District of Concepcion in terms of new normal class management.

\begin{tabular}{llcc}
\hline \multicolumn{1}{c}{ Statements } & Mean & Verbal Interpretation \\
\hline 1. I make sure that lessons are explicitly explained in the module. & 4.22 & Very High \\
2. I make myself available to my students for any academic & 4.49 & Very High \\
$\begin{array}{l}\text { inquiry. } \\
\text { 3. I stimulate student's curiosity in learning by integrating real }\end{array}$ & 4.37 & Very High \\
$\begin{array}{l}\text { life situations. } \\
\text { 4. I tend to be enthusiastic and approachable to provide an } \\
\text { engaging environment when communicating with students. }\end{array}$ & 4.39 & Very High \\
5. I regularly monitor and identify who fail to engage in online, \\
$\begin{array}{l}\text { modular activities. } \\
\text { 6. I maintain personal contact with students to provide help and } \\
\text { support. }\end{array}$ & 3.84 & 4.35 & High \\
7. I establish and reiterate schedules for consultations with \\
$\begin{array}{l}\text { parents and students regarding problems met. } \\
\text { 8. I develop a plan to help guide the students in their studies at } \\
\text { home. }\end{array}$ & 4.48 & 4.50 & Very High \\
9. I acknowledge student accomplishments and provide positive \\
feedback.
\end{tabular}

Difference in the Degree of Teaching Readiness of School Teachers in Island Schools in the District of Concepcion and Some Variables

Difference in the degree of teaching readiness of public school teachers in island schools in the District of Concepcion is expressed in Table 7. The distribution of respondents by socio-demographic profile is presented below.

Most of the respondents, $62(36.0 \%)$, were aged between 30-39 years old and had been in the service, $84(48.8 \%)$, for five years less than ten years, $138(80.2 \%)$ were females; without post-graduate studies, 128(74.4\%); with average monthly income, 106(61.6); were married, 120(69.8) and were island residents, $123(71.5 \%)$.

Difference in the degree of teaching readiness of island schools' teachers in the District of Concepcion is formed. Results of the data indicated that there was no significant difference in degree of teaching readiness of island schools' teachers in the District of Concepcion considering age, sex, highest educational attainment, length of service, monthly income, civil status and residence had p-values higher than the .05 alpha thereby the null hypothesis was accepted. 
Table 7. Distribution of respondents by socio-demographic profile.

\begin{tabular}{|c|c|c|}
\hline Variable & Frequency & Percentage \\
\hline \multicolumn{3}{|l|}{ Age } \\
\hline 21-29 Years Old & 50 & 29.1 \\
\hline 30-39 Years Old & 62 & 36.0 \\
\hline 40-49 Years Old & 33 & 19.2 \\
\hline 50-59 Years Old & 23 & 13.4 \\
\hline $60-65$ Years Old & 4 & 2.3 \\
\hline Total & 172 & 100.0 \\
\hline \multicolumn{3}{|l|}{ Sex } \\
\hline Male & 34 & 19.8 \\
\hline Female & 138 & 80.2 \\
\hline Total & 172 & 100.0 \\
\hline \multicolumn{3}{|l|}{ Highest Educational Attainment } \\
\hline With Post-Graduate Studies & 44 & 25.6 \\
\hline Without Post-graduate Studies & 128 & 74.4 \\
\hline Total & 172 & 100.0 \\
\hline \multicolumn{3}{|l|}{ Length of Service } \\
\hline Below Five Years & 46 & 26.7 \\
\hline Five Years Less Than Ten Years & 84 & 48.8 \\
\hline Ten Years and Above & 42 & 24.4 \\
\hline Total & 172 & 100.0 \\
\hline \multicolumn{3}{|l|}{ Monthly Income } \\
\hline Low (Below Php 9,999) & 22 & 12.8 \\
\hline Average (Php 10,000-Php 19,999) & 106 & 61.6 \\
\hline High (Php 20,000 and above & 44 & 25.6 \\
\hline Total & 172 & 100.0 \\
\hline \multicolumn{3}{|l|}{ Civil Status } \\
\hline Single & 51 & 29.7 \\
\hline Married & 120 & 69.8 \\
\hline Widowed & 1 & .6 \\
\hline Total & 172 & 100.0 \\
\hline \multicolumn{3}{|l|}{ Residence } \\
\hline Island Resident & 123 & 71.5 \\
\hline Non-Island Resident & 49 & 28.5 \\
\hline Total & 172 & 100.0 \\
\hline
\end{tabular}

Table 8. Difference in the degree of teaching readiness of school teachers in island schools in the District of Concepcion and some variables.

\begin{tabular}{|c|c|c|c|}
\hline Socio-demographic Profile & t-Value/Fvalue & Sig. & Probability \\
\hline Age & .663 & .619 & n.s. \\
\hline Sex & -.174 & .862 & n.s. \\
\hline Highest Educational Attainment & .215 & .830 & n.s. \\
\hline Length of Service & .419 & .659 & n.s. \\
\hline Monthly Income & .241 & .786 & n.s. \\
\hline Civil Status & .928 & .397 & n.s. \\
\hline Residence & -1.782 & .076 & n.s. \\
\hline
\end{tabular}

This implied negligible difference on teachers' teaching readiness considering the socio demographic profile of the respondents. It means regardless of profile the teachers were ready to teach learners. Results consisted to Cabardo (2010) that the level of readiness of Grade I and II teachers on Mother Tongue-Based Multilingual Instruction was moderately ready and the level of instructional competence was proficient. Similarly (Singh \& Chan, 2014; Summaka, Baglibel, and Samancioglu, 2010) successful implementation of digital technology into the curriculum relies heavily on teachers' readiness and willingness to adopt technology. Assertive teachers can integrate digital technology to supplement and support the curriculum, facilitate teachers' work, and encourage student-centered learning (Ertmer, Ottenbreit-Leftwich, Sadik, 
Sendurur, and Sendurur, 2012). As Chinooneka and Mupa, 2015 posted teachers' failure to use a variety of media in the teaching and learning process resulted into failure in grasping subject content. Teachers who pursue higher education must enhance their digital capabilities to cope with the demands of the present teaching and learning situations. Findings revealed the degree of teaching readiness of teachers were similar considering residence. It showed also that home location uses were addressed by providing teachers and parents with the right tools and techniques to utilize digital learning amid the COVID-19 crisis, the Department of Education and Globe Telecom, organized e-skwela webinar to discuss learning at home if classes will continue to be suspended or disrupted. Globe my Business tied up with DepEd for the second e-skwela webinar session with the theme "Making Homes the Extended Classroom: Parent-Teacher Collaboration in the time of COVID-19." The e-skwela series is intended to help faculty members and parents integrate technology tools and interactive activities at home, collaborative and reflective, in order to maximize learning experience (Malipot, 2020).

\section{Difference in the Level of Teachers' Capability in Island Schools in the District of Concepcion and Some Variables}

Data on the difference in the level of teachers' capability in island schools in the District of Concepcion revealed insignificant difference in all variables. The hypothesis was accepted since the computed values exceeded the 5\% level of significance. In support, studies have shown that the variables posed significant and insignificant differences on teacher's capabilities that included instruction and class management. Coined from Palloff and Pratt (2013) successful online instructors promote and facilitate students' active communication, interaction, collaboration, and engagement throughout the online course (Palloff and Pratt, 2013); BuabengAndoh (2012), consider technological, individual, organizational, and institutional factors when planning; consider the complex role and new tasks challenges of teacher in modern classroom (Zuljan and Vogrinc, 2011); Dwiyogo's (2014) on current trends of combines face-to-face, offline (computer interactive) and online (internet) learning and Singh and Chan (2017) investigated teacher capability to implement the ICT integration in teaching and learning; Abarro (2018) civil status is significantly associated with the performance of teachers and Ahmed, M., Hussain, I. Ahmed, S., and Din, M. (2012) that personal factors affect the performance of teachers. Findings of the authors corroborated with the current study, hence the inclusion.

Table 9. Difference in the level of teachers' capability in island schools in the District of Concepcion and some variables.

\begin{tabular}{|c|c|c|c|}
\hline Socio-demographic Profile & t-Value/Fvalue & Sig. & Probability \\
\hline Age & 1.027 & .395 & n.s. \\
\hline Sex & .791 & .430 & n.s. \\
\hline Highest Educational Attainment & -1.134 & .258 & n.s. \\
\hline Length of Service & .456 & .635 & n.s. \\
\hline Monthly Income & .319 & .727 & n.s. \\
\hline Civil Status & 1.979 & .141 & n.s. \\
\hline Residence & -1.301 & .195 & n.s. \\
\hline
\end{tabular}

\section{Relationship between the Degree of Teaching Readiness and Level of Teachers' Capability in Island} Schools in the District of Concepcion

Relationships on the degree of teaching readiness and level of teachers' capability in island schools in the District of Concepcion as perceived by teachers were expressed in Table 6. It disclosed highly positive correlation between scores in determining the degree of teaching readiness and level of teachers' capability, $(\mathrm{r}=.722, \mathrm{p}=.000)$ in island schools in District of Concepcion. The null hypothesis is not accepted. This indicated the degree of teaching readiness improves as level of teachers' capability to teach in a blended modality in terms of online skills and class management improves. Hence, the development of teaching competence would likely to result in a more capable and effective teachers in the delivery of essential competences in the new normal in education. As Yunos (2015) found best teaching and pedagogy practice apply various methods, strategies, techniques, approaches and resources to make sure teacher-cantered, pupil-cantered and resource-cantered combined in harmony helped pupils stay focused during teaching and learning session. While Salehudin, Hassan and Hamid (2015) stated new direction of teaching with creative 
planning and Puteh, Ghazali, Tamyis and Ali (2012) recognized the weaknesses of teaching that was caused by low teachers' expertise in teaching strategy and understanding the visions of new curriculum reformation. These views correlated with the findings of the study since teaching readiness correlated with teacher's capability.

Table 10. Relationship between the degree of teaching readiness and level of teachers' capability in island schools in the District of Concepcion.

\begin{tabular}{lcccc}
\hline \multicolumn{1}{c}{ Variables } & $\mathrm{N}$ & Pearson R & Sig. & Probability \\
\hline $\begin{array}{l}\text { Degree of Teaching } \\
\text { Readiness }\end{array}$ & 172 & & & \\
$\begin{array}{l}\text { Level of Teachers' } \\
\text { Capability }\end{array}$ & 172 & .722 & .000 & $\begin{array}{c}\text { Highly } \\
\text { Significant }\end{array}$ \\
\hline
\end{tabular}

\section{Conclusions}

Based on the findings of the study, the following conclusions are drawn:

1. Teachers in the island schools in the District of Concepcion are ready to teach under the present circumstances. They have prepared themselves with the basic technological requirements and instructional materials needed in the delivery of instruction under the new normal.

2. Teachers in the island schools in the District of Concepcion exhibited teaching readiness through preparation of basic technological requirements and instructional materials needed in the delivery of instruction under the new normal.

3. Teachers in the island schools in the District of Concepcion are generally prepared to engage in the new normal educational setting. They have equipped themselves with the needed online skills and demonstrate preparedness in handling and managing the class under the present circumstances.

4. Teachers in the island schools in the District of Concepcion have updated their online training skills and attended online class demonstration training in equipped themselves with the needed online skills and demonstrate preparedness in handling and managing the class under the present circumstances.

5. The degree of teachers' teaching readiness in island schools in the District of Concepcion is the same regardless of their selected profile.

6. The teachers is the island schools of Concepcion exhibited similarity in the degree of teaching readiness regardless of their profile.

7. The level of teachers' capability in island schools in the District of Concepcion is the same regardless of their selected profile.

8. There was no variation in the teacher's capability irrespective of their profile.

9. The degree of teaching readiness and the level of teachers' capability in island schools in the District of Concepcion are mutually dependent.

10. Interrelationship in the level of teacher's readiness and teachers capability was evident in island schools of district of Concepcion.

\section{Implications}

To address teachers' apprehensions on new technologies, hands-on training will have greater effect on their capabilities to operate the gadgets. Unless they are exposed to the training several times, they will be more at ease operating the gadgets. Likewise, exposure of teachers to different platforms may be undertaken at the same time. Only through these endeavours that will make education attain a higher level of competence. The government should focus first who are the primary contact in building competitive students', their needs should be the first priority. Nonetheless non-government agencies may be tapped for support and donations in terms of computers, generators or solar panels and provision of internet connectivity to enhance teaching readiness in this digital world.

\section{References}

Abarro (2018). Factors Affecting the Performance of Public School Teachers

Abdous, M. H. (2011). A process-oriented framework for acquiring online teaching competencies. Journal of Computing in Higher Education, 23(1), 60-77.

Bailey, C. J., \& Card, K. A. (2011). Effective pedagogical practices for online teaching: Perception of experienced instructors. The Internet and Higher Education, 12(3), 152- 155.

Balajadia, 2015. Gauging the ICT-Based Teaching Readiness of Preservice Teachers in The Light Of 21st 
Century Education. People: International Journal of Social Sciences ISSN 2454-5899. College of Education, University of the Assumption, City of San Fernando (Pampanga) Philippines.

Baran, E., Correia, A. P., \& Thompson, A. (2013). Tracing successful online teaching in higher education: Voices of exemplary online teachers. Teachers College Record, 115(3), 1-41

Boelens, R., De Wever, B., \& Voet, M. (2017). Four key challenges to the design of blended learning: A systematic literature review. Educational Research Review, 22, 1-18.

Bonanno, P. (2011). Developing an instrument to assess teachers' readiness for technology-enhanced learning. 14th International Conference on Interactive.

Bronfenbrenner, U. (1974). Developmental research, public policy, and the ecology of childhood. Child development, 45(1), 1-5.

Buabeng-Andoh, C. (2012). An exploration of teachers' skills, perceptions and practices of ICT in teaching and learning in the Ghanaian second cycle schools. Contemporary Educational Technology, 3(1), 36-49.

Cabardo (2010). Level of Readiness and Instructional Competence of Grade I and II Teachers in the Mother Tongue-Based Multilingual Instruction. Hagonoy National High School, Guihing, Hagonoy, Davao del Sur, 8006, Philippines.

Chinooneka, T.I. \&Mupa, P. (2015). Factors Contributing to Ineffective Teaching and Learning in Primary Schools: Why Are Schools in Decadence? J. Educ. Pract., 6(19):125- 132.

Ertmer, P. A., Ottenbreit-Leftwich, A. T., Sadik, O., Sendurur, E., \& Sendurur, P. (2012). Teacher beliefs and technology integration practices: A critical relationship. Computers and Education, 59(2), 423435.

Fleck, J. (2012). Blended learning and learning communities: Opportunities and challenges. Journal of Management Development, 31(4), 398411.

Lim, C. P., Chai, C. S., \& Churchill, D. (2011). A framework for developing pre-service teachers' competencies in using technologies to enhance teaching and learning. Educational Media International Journal, 48(2), 69-83. doi:10.1080/09523987.2011.576512. 